\title{
ANALISIS HUKUM PEMBATALAN SERTIFIKAT HAK MILIK ATAS TANAH KARENA MENJALANKAN PUTUSAN PENGADILAN
}

\author{
Legal Analysis of the Cancellation of Freehold Title of Land for Running Court Decisions \\ Nurul Fitria' ${ }^{1}$, Muh. Arfah Pattereng ${ }^{2}$, Zulkifli Makkawaru
${ }^{1}$ Badan Pertanahan Nasional Kabupaten Gowa
${ }^{2}$ Program Studi Ilmu Hukum, Program Pascasarjana, Universitas Bosowa \\ Email: daengngagi4@gmail.com \\ Diterima: 07 Januari 2021 \\ Dipublikasikan: 07 Juni 0221
}

\begin{abstract}
ABSTRAK
Dalam era globalisasi dan modernisasi saat ini, tanah memegang peranan sentral dalam kehidupan manusia serta merupakan permasalahan yang paling pokok dan krusial. Terlihat dari banyaknya perkara perdata maupun pidana yang diajukan ke pengadilan, antara lain menyangkut sengketa tata usaha Negara mengenai penertiban sertipikat tanah dan berbagai perbuatan melawan hukum lainnya. Negara mengakomodir perkembangan ini melalui kewajiban pemerintah untuk menyelenggarakan pendaftaran tanah, baik secara sistematik maupun sporadik dengan tujuan untuk menjamin kepastian hukum dan memberikan perlindungan hukum kepada pemegang hak atas tanah. Penelitian yang dilakukan adalah penelitian kepustakaan yang bersifat deskriptif analitis yang menggambarkan mengenai kegiatan pendaftaran tanah beserta berbagai permasalahan seputarnya, khusus mengenai pembatalan Sertipikat Hak Milik berdasarkan Putusan Pengadilan Nomor : 634PK/PDT/2012 yang kemudian dianalisa guna memberikan saran atau jalan keluar bagi permasalahan yang terjadi. Dari penelitian tersebut diketahui bahwa sertipikat hak atas tanah merupakan alat pembuktian yang kuat, bukan alat pembuktian yang mutlak.
\end{abstract}

Kata Kunci: Putusan Pengadilan, Pembatalan Sertifikat, Hak Milik

\begin{abstract}
Land held a central role in human life and has become the main and crucial problem in this globalization and modernization era. It can be seen from the number of civil and criminal cases that have been filed to the court that concerns to State administrative disputes regarding land certificate publication and other illegal acts. The state accommodates this development through the government's obligation to carry out land registration, both systematically and sporadically, with the main objective of ensuring legal certainty and providing legal protection to land holders. Regarding certificate cancellation on land disputes number: 01006/Panciro on 28 of November 2013 elaborated as well on survey document Number 00541/Panciro 2013 on 15 of November 2013, 5.596 M2 areas. Library research has been done, descriptive analysis, to answer the question above which described about land registration activity with some problems around, concerning land rights certificate cancellation exclusively based on the verdict of the court Number: 634PK/PDT/2012 which analyzed to give suggestion and solution to the problem. The result of the research showed that the land rights certificate is not absolute verification but strong.
\end{abstract}

Keywords: Court Decisions, Certificate Cancellation, Freehold Title

\section{PENDAHULUAN}

Keterkaitan antara tanah dengan kehidupan manusia sangat erat, dimana setiap individu pasti membutuhkan tanah dalam kehidupannya sebagai tempat bermukim, berusaha, beribadah dan bersosialisasi. Hubungan tiaptiap pribadi dengan tanah bersifat kontinu dan untuk jangka waktu yang sangat panjang karena dari awal kehidupan hingga mati, manusia pasti membutuhkan tanah.

Mekanisme untuk memberikan suatu hak atas tanah kepada seseorang atau badan hukum diselenggarakan melalui pendaftaran tanah. Hal ini dimaksudkan agar jelas subjek dan obyek (letak peruntukan suatu penggunaan tanah yang dapat dihaki oleh seseorang atau badan hukum), sehingga pemilik hak atas tanah itu dapat melakukan hak keperdataannya terhadap bidang tanah tersebut dan untuk memberikan informasi mengenai eksistensi suatu bidang tanah dengan pemegang hak yang bersangkutan. Pendaftaran tanah di Indonesia didasarkan pada Pasal 19 UUPA, yang diatur lebih lanjut dengan Peraturan Pemerintah Nomor 10 Tahun 1961 sebagaimana telah diubah dengan Peraturan Pemerintah Nomor 24 Tahun 1997 tentang Pendaftaran Tanah.

Tujuan utama diselenggarakannya pendaftaran tanah, antara lain adalah guna menjamin kepastian hukum dan memberikan perlindungan hukum kepada pemegang hak atas tanah oleh pemerintah, dimana nama yang terdaftar adalah nama yang secara yuridis dianggap sebagai pemilik tanah. Agar pemegang hak atas tanah dapat dengan mudah membuktikan bahwa dirinyalah yang berhak atas tanah yang bersangkutan maka diberikan kepadanya sertipikat sebagai surat tanda buktinya dan merupakan alat bukti yang kuat. Hal ini sebagaimana diuraikan dalam penjelasan Pasal 32 ayat (1) Peraturan 
Pemerintah Nomor 24 Tahun 1997, bahwa sertipikat merupakan surat tanda bukti hak yang berlaku sebagai alat pembuktian yang kuat mengenai data fisik dan data yuridis yang termuat di dalamnya, sepanjang data fisik dan data yuridis tersebut sesuai dengan data yang ada dalam surat ukur dan buku tanah yang bersangkutan .

Dalam Pasal 11 ayat (3) Peraturan Menteri Agraria/Kepala BPN No. 11 Tahun 2016 tentang Penyelesaikan Kasus Pertanahan menyatakan bahwa Pembatalan keputusan tentang suatu hak atas tanah karena menjalankan keputusan yang mengandung cacat administrasi dalam penerbitan atau melaksanakan putusan pengadilan yang telah berkekuatan hukum tetap dapat dilakukan karena pejabat yang berwenang tanpa permohonan. Permohonan pembatalan hak dapat diajukan langsung kepada Menteri atau pejabat yang ditunjuk atau melalui Kepala Kantor Pertanahan di daerah tersebut.

Pasal 11 ayat (3) Peraturan Menteri Agraria/Kepala BPN No. 11 Tahun 2016 tentang Penyelesaikan Kasus Pertanahan dapat menyelesaikan kasus - kasus di Bidang Pertanahan dan menyatakan bahwa Sengketa atau konflik yang menjadi kewenangan Kementerian meliputi : kesalahan prosedur dalam proses pengukuran, pemetaan dan/ atau perhitungan luas; kesalahan prosedur dalam proses pendaftaran penegasan dan/ atau pengakuan hak atas tanah bekas milik adat; kesalahan prosedur dalam proses penetapan dan/ atau pendaftaran hak tanah; kesalahan prosedur dalam proses penetapan tanah terlantar; tumpang tindih hak atau sertipikat hak atas tanah yang salah satu alas haknya jelas terdapat kesalahan; kesalahan presedur dalam proses pemeliharaan data pendaftaran tanah; kesalahan prosedur dalam proses penertiban sertipikat pengganti; kesalahan dalam memberikan informasi data pertanahan; kesalhan prosedur dalam memberikan izin; penyalahgunaan pemanfaatan ruang; atau kesalahan lain dalam penerapan peraturan perundang - undangan. Sengketa dan konfllik selain berdasarkan uraian di atas, dapat diketahui bahwa meskipun sertipikat telah diterbitkan dan mempunyai kekuatan pembuktian yang kuat, bukan tidak dapat di gugatan oleh orang lain yang berkeberatan atau disangkal.

\section{METODE}

Metode penelitian menggunakan penelitian hukum empiris, bertujuan memberikan penjelasan terhadap praktek-praktek hukum dari kebijakan pemerintah terhadap pendaftaran tanah. Di dukung Jenis Data yaitu Data Primer dan Data Sekunder. Data primer diperoleh dari hasil wawancara di Kantor Pertanahan Kabupaten Gowa. Data sekunder terdiri dari bahan hukum primer yaitu Undang-undang, Peraturan Pemerintah dan Peraturan Menteri, Putusan Pengadilan, media elektronik, jurnal serta bahan kepustakaan lainnya dan bahan hukum sekunder menguji keabsahan empiris memberikan penjelasan terhadap praktek praktek hukum bagaimana hukum itu dilaksanakan termasuk proses penegakan hukum dan pendekatan kasus. Tehnik pengumpulan data yang digunakan yaitu melalui studi kepustakaan dan wawancara untuk mengetahui pendapat persepsi, informasi untuk memberikan informasi sehingga dapat terwujud tujuan hukun yaitu kepastian hukum yang adil. Tehnik analisis data bersifat deskriptif kualitatif, bertujuan mendeskripsikan tentang kebijakan pendaftaran terciptanya kepastian hukum di bidang Pertanahan dengan cara penelitian wawancara.

\section{HASIL DAN PEMBAHASAN}

Pembatalan Sertipikat Hak Milik Atas Tanah Karena Menjalankan Putusan Pengadilan.

1. Anlisis Gugatan

a. Pada Pengadilan tingkat pertama analisis penggugat dalam surat Gugatan tertanggal 19 November 2009 dengan Register perkara Nomor : 40/PDT.G/2008/PN.SUNGGU, telah mengajukan gugatan kepada Tergugat dengan alasan - alasan sebagai berikut :

1) Bahwa adapun yang menjadi pihak Tergugat dlam perkara ini adalah $\mathrm{Hj}$. Hajjiah, R, umur 60 bertempat tinggal dikampung Jatia, Kelurahan Mata Allo, Kecamatan Bajeng, Kabupaten Gowa, selaku ahli waris satu - satunya dari Almarhum KEBO BINTI KAMASANG (pihak dalam perkara terdahulu) yang putusannya telah memiliki kekuatan hukum yang pasti yakni dalam Perkara Perdata Nomor 37/Pdt.G/1998/PN.Sungg. yang disaat ini dijadikan dasar dalam mengajukan Gugatan Pengosongan tersebut.

2) Bahwa adapun yang menjadi objek gugatan pengosongan ini adalah tanah sawah Personil Nomor 0006, Kohir Nomor 295 CI, seluas 5897 M2 yang terletak di Desa Panciro, Kecamatan Bajeng, Kabupaten Gowa, dengan batas - batas yakni:

- Sebelah Utara dengan sawah H. Lalli / Ambo Enre;

- Sebelah Timur dengan tanah Kebo Binti Kamasang;

- Sebelah Selatan dengan saluran irigasi / jalan desa;

- Sebelah Barat dengan tanah sawah Murtalang Binti Bohari:

3) Bahwa pada awalnya Penggugat adalah Tergugat dalam perkara Perdata Nomor : 37/Pdt.G/1998/PN.Sungguminasa yang dikala itu digugat oleh Almarhum KEBO BINTI KAMASANG dengan objek perkara sebagaimana yang disebutkan dalam Gugatan Pengosongan ini dan sekarang telah memiliki kekuatan hukum yang tetap yang selanjutnya menjadi dasar ataupun alasan diajukannya Gugatan Pengosongan disaat ini.

4) Bahwa dalam putusan Mahkamah Agung RI Nomor 1125 K/PDT/2001, tanggal 29 Januari 2004, juncto Putusan Pengadilan Tinggi Sulawesi Selatan Nomor : 69/PDT/2000/PT.SULSEL, Tanggal 4 Juli 2000, Juncto Putusan Pengadilan Negeri Sungguminasa Nomor 
37/PDT.G/1998/PN.SUNGG, Tanggal 12 Juli 1999 yang ketiganya menyebutkan dalam putusannya bahwa Tergugat adalah pemilik sah atas tanah persil Nomor 0006, Kohir 259 CI, seluas 5897 M2 yang terletak Di Desa Panciro, Kecamatan Bajeng Kabupaten Gowa, Sulawesi Selatan yang selanjutnya menjadi objek dalam Gugatan Pengosongan ini yang berasal dari Jual Beli dengan system pembayaran angsusran;

5) Bahwa adapun terhadap sisa angsuran sebesar Rp. 15.970.000,- (lima belas juta sembilan ratus tujuh puluh ribu rupiah) yang menjadi kewajiban Penggugat terhadap Almarhum KEBO BINTI KAMASANG (ibu kandung Tergugat Hj. Hajjiah, R) tersebut berdasarkan putusan - putusan a quo tidak membatalkan Jual Beli dimaksud, dan selanjutnya Penggugat memohon ke Pengadilan Negeri Sungguminasa untuk di konsinysikan perihal pembayaran sisa angsuran tersebut;

6) Bahwa oleh karena Gugatan pengosongan ini didasarkan pada bukti - bukti yang kuat yakni berupa putusan - putusan Pengadilan yang telah memiliki keuatan hukum yang tetap maka adalah patut dan dibenarkan menurut hukum apabila dimohonkan putusan serta merta (uit voor bij voraad) yang didahulukan sekalipundiajukan verset, banding ataupun kasasi;

7) Bahwa untuk menjadi Gugatan pengosongan ini dapat dilaksanakan dan guna menghindari Tergugat mengalihkan objek sengketa maka adalah wajar dan patut dimohonkan penyitaan (CB) atas objek dimaksud.

b. Dalam perkara banding perdata penggugat menolak esepsi tergugat konvensi untuk seluruhnya sebagaimana yang tertera dalam putusan Pengadilan Negeri tanggal 30 September 2009 Nomor: 40/Pdt.G/2008/PN.SUNGG.

c. Pada gugatan tingkat kasasi bahwa pada tanggal 22 Desember 1992 telah dibuat suatu kesepakatan yang tertuang dalam Surat Perjanjian antara Penggugat Rekonvensi dengan Tahir Daming menyangkut tanah Persil No. 0006, Kohir No. 908 CI seluas 4.049 M2 sebagai akibat karena adanya konflik hukum yang terjadi sebelumnya, dimana dalam perjanjian tersebut ditentukan bahwa untuk bagian Penggugat Rekonvensi seluas 15 are atau $1.500 \mathrm{M} 2$ dan untuk Tahir Daming seluas 25 are atau $2.500 \mathrm{M} 2$. Adapun batas bagian Penggugat Rekonvensi seluas 15 are atau 1.500 M2 setelah dilakukan pembagian adalah sebagaimana tersebut dengan jelas dalam surat gugatan rekonvensi;

Bahwa seharusnya tanah seluas 15 are atau $1.500 \mathrm{M} 2$ di atas telah dinikmati oleh Penggugat Rekonvensi, namun kenyataannya tanah milik Penggugat Rekonvensi telah dikuasai oleh Tergugat Rekonvensi sebagai pemilik sah tidak pernah mengalihkan dalam bentuk apapun tanah tersebut kepada Tergugat Rekonvensi ataupun kepada pihak lain;
Bahwa tanah milik Penggugat Rekonvensi ysng dikenal dengan Persil No. 0006, Kohir No. 908 CI, seluas 5.897 M2 telah dilakukan jual beli dibawah tengan secara mengangsur kepada Tergugat Rekonvensi sebagai pembeli pada tahun 1994 dengan ketentuan harga sebesar Rp. 10.000,- (sepuluh ribu rupiah) permeter, namun kenyataannya sampai diajukan gugatan rekonvensi ini Tergugat Rekonvensi belum melunasi keseluruhan harga pembeli tersebut, padahal Penggugat Rekonvensi sebagai penjual tanah berkali - kali mengingatkan Tergugat Rekonvensi untuk menyelesaikan kewajban tersebut, namun tidak pernah diindahkan;

Bahwa perbuatan hukum menerbitkan akta jual beli di atas tanah Pesil No. 0006, Kohir No. 908 CI seluas 15 are atau 1.500 M2 milik Pengguat Rekonvensi ke atas nama Tegugat Rekonvensi jelas merupakan suatu perbuatan melawan hukum karena merugikan kepentingan hukum Penggugat Rekonvensi, demikian pula halnya belum adanya pelunasan pembayaran harta tanah Persil No. 0006, Kohir No. 295 CI seluas 5.897 M2 oleh Tergugat Rekonvensi, juga merupakan atau perbuatan yang sangat merugikan kepentingan hukum/hak bagi Penggugat Rekonvensi, oleh karena itu cukup beralasan perbuatan penertiban akta jual beli di atas tanah milik Pengguat Rekonvensi seluas 15 are atau 1.500 M2 telah dapat dikualifisir sebagai perbuatan melawan hukum, sedangkan untuk perbuatan Tergugat Rekonvensi atas tanah Persil No. 0006, Kohir 295 CI seluas 5.897 M2 yang tidak melunasi harga pembeliannya telah dapat dikualifisir sebagai perbuatan cidera janji;

Bahwa oleh karena perbuatan hukum di atas jelas jelas merupakan perbuatan bertentangan dengan hukum yang berlaku, maka sangat beralasan apabila Akta Jual Beli No. 34/KB/1995 dan Akta Jual Beli di bawah tangan dinyatakan batal.

2. Amar Putusan

Amar putusan perkara perdata perdata Pengadilan Negeri Sungguminasa No. 37/Pdt.G/1998/PN.Sungg disebutkan bahwa dalam ekspesi :

- Menolak Ekssepsi Tergugat -Tergugat untuk seluruhnya;

- Menghukum penggugat untuk membayar biaya perkara dan seterusnya.

Bahwa selanjutnya Putusan Pengadilan Negeri tersebut telah dikuatkan pula oleh Pengadilan Tinggi Sulawesi Selatan dalam putusan No.67/PDT/2001/PT. Sul-Sel dan Mahkamah Agung RI dalam putusan tersebut diatas dapat disimpulkan bahwa orang tua tergugat yaitu Kebo Binti Kamasang pernah mengajukan gugatan kepada Drs Abdul Salam Said Mdkk untuk membatalkan perjanjial Jual Beli antara Kebo Binti Kamasang dan Dra Abdul Salam Said, Mdkk, akan tetapi gugatan tersebut dinyatakan ditolak oleh Pengadilan.

Bahwa setelah Majelis Hakim mempelajari dengan seksama putusan perkara perdata No. 37/Pdt.G/1998/PN.Sungg jo Putusan 67/PDT/2001/PT.Sul-Sel jo Putusan Mahkamah Agung RI No. 1125 K/PDT/2001, maka Majelis Hakim 
berpendapat bahwa ternyata Putusan tersebut berkaitan dengan pembatalan perjanjian jual beli dan bukan mengenai sengketa kepemilikan tanah serta tidak terdapat pula dalam amar putusan yang mengatakan Tergugat (Penggugat sekarang) adalah pemilik sah atas tanah persil No. 0006 Kohir 259 CI seluas 897 M2 yang terletak di Desa Panciro Kecamtan Bajeng, Kabupaten Gowa, Sulawesi Selatan.

Bahwa berdasarkan hal tersebut diatas, maka majelis berkesimpulan bahwa gugatan perngosongan yang dimohonkan oleh Penggugat terhadap tanah persil No. 0006 kohir 259 CI seluas 5897 M2 yang terlatak di desa Panciro Kecamatan Bajeng Kabupaten Gowa Sulawesi Selatan adalah keliru dan tidak beralasan karena putusan tersebut hanya menolak pembatalan perjanjian jual beli. Sehingga dengan ditolaknya gugatan Kebo Binti Kamasang tersebut, tanah yang dimohonkan pengosongan tersebut belum menjadi milik Penggugat karena sesuai dengan perjanjian tanah tersebut belum lunas dibayar walaupun Penggugat ingin mengkonsinyasikan sisa angsurannya ke Pengadilan Negeri Sungguminasa.

Gugatan pengosongan hanya dapat dilakukan oleh Penggugat apabila tanah yang dimohonkan pengosongan tersebut telah menjadi milik Penggugat

Bahwa mengenai bukti P-5 sampai dengan P-20 bukanlah bukti mengenai kepemilikan tanah tersebut, bukti - bukti tersebut hanya menunjukkan bahwa telah dilakukan jual beli tanah yang pembayarannya secara bertahap atas putusan Mahkamah Agung RI No. 1125 K/PDT/2001 tanggal 29 Januari 2004 jo putusan Pengadilan Tinggi Sulawesi Selatan No. 69/PDT/2000/PT.Sul-Sel, tanggal 4 Juli 2000 jo putusan Pengadilan Negeri Sungguminasa No. 37/Pdt.G/1998/PN.Sungg tanggal 12 Jual 1999 yang kemudian melahirkan bukti T-16, T-17 dan T-18.

Bahwa berdasarkan bukti tersebut, Majelis Hakim berpendapat bahwa benar tanah obyek sengketa adalah milik Tergugat selaku ahli waris dari Kebo Binti Kamasang.

Bahwa berdasarkan pertimbangan di atas Penggugat tidak mampu membuktikan dalil - dalil gugatan sedangkan Tergugat mampu membutikan dalil - dalil sangkalannya/bantahannya, sehingga oleh karenanya gugatan Penggugat harus ditolak untuk seluruhnya.

Bahwa oleh karena gugatan Pengguat ditolak untuk seluruhnya, maka kepada Penggugat haruslah dihukum untuk membayar ongkos perkara yang bersarnya akan disebutkan dalam amar putusan.

3. Prosedur Pembatalan Sertipikat

a. Prosedur Pembatalan Sertipikat di Kantor Pertanahan

Berdasarkan keterangan yang disampaikan oleh Muh. Imran Hamid Dm, S.H, Kepala Sub Seksi Penanganan Sengketa, Konflik dan Perkara Pertanahan menyatakan bahwa permohonan pembatalan hak atas tanah oleh pemohon jumlah tidak menentu setiap tahun dan prosesnya berbeda - beda tergantung analis perkasus, ada yang memang permohonannya tersebut dianggap cacat administrasi karena menjalankan putusan namun ada pula yang permohonan tersebut bukan merupakan kewenangan BPN Kabupaten Gowa.

Terkait proses pembatalan sertipikat secara umum yaitu dengan dibuatkan analisis dilakukan pemeriksaan lapang, gelar internal, dibuatkan laporan penyelesaikan perkara sebagaimana diatur dalam PERMEN Agraria/ Kepala BPN No 11 tahun 2016 tentang penyelesaian kasus pertanahan dan apabila setiap prosedur telah dilaksanakan maka akan diusulkan ke Kantor Wilayah Badan Pertanahan Provinsi Sulawesi Selatan dan dari keseluruhan proses tersebut biasanya selesai dikerjakan paling cepat selama 3 bulan. Lebih lanjut terkait putusan pembatalan hak atas tanah sebagai dasar pemohon untuk mengajukan proses pembuatan sertipikat terkhusus di BPN Kabupaten Gowa maka kami menindaklanjuti putusan tersebut dengan melakukan pembuatan sertipikat sebagaimana amar putusan yang berkekuatan hukum tetap atau inkcraht namun saat penelitian lapangan lokasinya tidak dikuasai oleh pemohon pembatalan, disarakan untuk pemohon mengajukan eksekusi ke Pengadilan terlebih dahulu.

Alasan pembatalan sertifikat hak atas tanah adalah karena adanya cacat hukum administratif, seperti kesalahan perhitungan dan luas tanah, sehingga menyerobot tanah lainnya, tumpang tindih hak atas tanah, kesalahan prosedural, atau perbuatan lain, seperti pemalsuan surat.

Hal ini dimohonkan secara tertulis kepada Kantor Pertanahan yang letak objeknya di daerah tersebut :

Lampiran berkas-berkas yang harus dipersiapkan seperti:

1) Foto copy bukti identitas, Kartu Tanda Penduduk (KTP);

2) Surat Pemberitahuan Pajak Terhutang (SPPT)/ Pajak Bumi dan Bangunan (PBB) (bagi perorangan) atau foto copy akta pendirian (bagi badan hukum);

3) Foto copy Kartu Keluarga (KK).

4) Foto copy Alas Hak dan/atau sertifikat berkasberkas lain yang berkaitan dengan permohonan pembatalan tersebut.

Orang yang datang ke Kantor Pertanahan untuk mengajukan sebuah proses sertipikat, entah itu pendaftaran atau membatalkan sertipikat dan sebagainya disebut Pemohon. Pemohon diarahkan untuk membawa berkas - berkas yang telah disampaikan petugas loket.

b. Prosedur Pembatalan Sertipikat di Pengadilan

Perbuatan melawan hukum diatur dalam Pasal 1365 Kitab Undang-Undang Hukum Perdata (KUHPerdata), berbunyi: "Tiap perbuatan yang melanggar hukum dan membawa kerugian kepada orang lain, mewajibkan orang yang menimbulkan kerugian itu karena kesalahannya untuk menggantikan kerugian tersebut", seperti contohnya, Seseorang menjual sebidang objek tanah kepada pembeli. Pembeli belum melunasi pembayaran tersebut namun pembeli sudah mengajukan proses pembuatan sertipikat tanah. 
Yang perlu diketahui bahwa Pasal 32 ayat (2) Peraturan Pemerintah Nomor 24 Tahun 1997 tentang Pendaftaran Tanah yang berbunyi:

Dalam hal atas suatu bidang tanah sudah diterbitkan sertifikat secara sah atas nama orang atau badan hukum yang memperoleh tanah tersebut dengan itikad baik dan secara nyata menguasainya, maka pihak lain yang merasa mempunyai hak atas tanah itu tidak dapat lagi menuntut pelaksanaan hak tersebut apabila dalam waktu 5 (lima) tahun sejak diterbitkannya sertifikat itu tidak mengajukan keberatan secara tertulis kepada pemegang sertifikat dan Kepala Kantor Pertanahan yang bersangkutan ataupun tidak mengajukan gugatan ke Pengadilan mengenai penguasaan tanah atau penerbitan sertifikat tersebut.

Namun daluwarsa tidak mutlak selama bisa dibuktikan bahwa perolehan tanah tersebut dilakukan tidak dengan iktikad baik.

Efektivitas Putusan Pengadilan Dalam Memenuhi Unsur Kepastian Hukum dalam Hal Pembatalan Sertipikat Hak Milik Atas Tanah.

1. Kesesuaian dengan Peraturan Perundangan Undangan

a. Undang - Undang No. 5 Tahun 1960;

Pasal 23 ayat 1 intinya "Hak Milik demikian pula peralihan, hapusnya dan pembebanannya dengan Hak-hak lain harus didaftarkan menurut ketentuan-ketentuan yang dimaksud dalam pasal 19 dan pasal 23 ayat 2 intinya "Pendaftaran yang dimaksud dalam ayat 1 merupakan alat pembuktian yang kuat mengenai hapusnya Hak milik serta sahnya peralihan dan pembebanan Hak tersebut";

b. Peraturan Pemerintah Republik Indonesia No. 24 Tahun 1997;

Pasal 52 ayat (1) huruf b pendaftaran hapusnya suatu Hak atas tanah, Hak pengelolaan dan Hak milik atas satuan rumah susun dilakukan oleh Kepala Kantor Pertanahan dengan membutuhkan catatan pada buku tanah dan surat ukur serta memusnahkan sertipikat Hak yang bersangkutan berdasarkan salinan surat keputusan pejabat yang berwenang, bahwa Hak yang bersangkutan telah dibatalkan atau dicabut";

c. Peraturan Presiden Republik Indonesia No. 10 Tahun 2006;

Pasal 3 huruf "t" intinya Badan Pertanahan Nasional menyelenggarakan fungsi pembatalan dan penghentian hubungan hukum antara orang, dan/atau badan hukum dengan tanah sesuai dengan ketentuan peraturan perundang-undangan yang berlaku;

d. Peraturan Menteri Negara Agraria/Kepala Badan Pertanahan Nasional No. 3 Tahun 1997; Pasal 131 ayat 2 huruf a intinya Pendaftaran hapusnya Hak atas tanah atau Hak Pengelolaan atau Hak Milik Atas Satuan Rumah Susun yang disebabkan oleh dibatalkannya atau dicabutnya Hak yang bersangkutan dilakukan oleh Kepala Kantor Pertanahan atas permohonan yang berkepentingan dengan melampirkan salinan keputusan pejabat yang berwenang yang menyatakan bahwa Hak yang bersangkutan telah batal, dibatalkan atau dicabut. e. Peraturan Kepala Badan Pertanahan Nasional Republik lndenesia No. 4 Tahun 2006; Pasal 3 huruf b intinya Kanwil BPN mempunyai fungsi pengkoordinasian, pembinaan, dan pelaksanaan survei, pengukuran, dan pemetaan, Hak tanah dan pendaftaran tanah, pengaturan dan penataan pertanahan, pengendalian pertanahan dan pemberdayaan masyarakat, serta pengkajian dan penanganan sengketa dan konflik pertanahan;

f. Peraturan Menteri Agraria dan Tata Ruang/Kepala Badan Pertanahan Nasional No. 11 Tahun 2016;

- Pasal 49 ayat (2) intinya bahwa amar putusan pengadilan yang telah memperoleh kekuatan hukum tetap, yang berkaitan dengan penerbitan, peralihan, pembataian Hak Atas tanah atas tanah dan/ atau pembatalan penetapan tanah terlantar antara lain b. menyatakan batal/tidak sah/tidak mempunyai kekuatan hukum Hak atas tanah.

- Pasal 56 ayat (1) intinya menyatakan dalam hal pelaksanaan putusan pengadilan sebagaimana dimaksud dalam Pasal 49. pelaksanaannya dilakukan sesuai dengan kewenangan pembatalan.

- Pasal 56 ayat (2) intinya menyatakan kewenangan pembatalan sebagaimana dimaksud pada ayat 1 rneliputi: a. Kepala Kantor Pertanahan. dalam hal keputusan konversi/penegasan/pengakuan, pemberian Hak Pembatalan Hak yang diterbitkan oleh Kepala Kantor Pertanahan.

Menurut Peraturan Menteri Agraria dan Tata Ruang/ Kepala Badan Pertanahan Nasional Republik Indonesia Nomor 11 Tahun 2016 Tentang Penyelesaian Kasus Pertanahan batalnya sertipikat karena cacat administrasi Pasal 11 ayat 3 Tahun 2016.

Berdasarkan permen tersebut sudah sesuai dengan keputusan Kepala Kantor Wilayah Badan Pertanahan Nasional Provinsi Sulawesi Selatan Nomor : 2/Pbt/BPN73/2019 tentang pembatalan sertipikat hak milik nomor 01006/ Panciro tanggal 28 November 2013 sebagaimana diuraikan 00541/Panciro/2013 tanggal 15 November 2013 seluas 5.596 M2 (lima ribu lima ratus sembilan puluh enam meter persegi) atas nama Drs. H. A. Salam Manruppai yang terletak di Desa Panciro, Kecamatan Bajeng, Kabupaten Gowa, Provinsi Sulawesi Selatan.

Pembatalan sertipikat tersebut mengikuti keputusan Pengadilan Negeri No. 634PK/PDT/2012

\section{Pertimbangan Hakim Terhadap Putusan}

Alasan Peninjauan Kembali dapat dibenarkan, karena meneliti dengan saksama memori Peni jauan Kembali tanggal 7 mei 2012 dan Kontra memori Peninjauan Kembali tanggal 21 Juli 2012 dihubungkan dengan putusan Judex Facti dalam hal ini putusan Pengadilan Tinggi Makassar yang membatalakn putusan Pengadilan Negeri Sungguminasa dan putusan Judex Juris yang menolak permohonan kasasi darinpemohon Kasasi, terdapat adanya kekhilafan Hakim atau kekeliruan yang nyata, dengan pertimbangan sebagai berikut: 
- Bahwa putusan Pengadilan Tinggi Makassar yang membatalkan putusan Pengadilan Negeri Sungguminasa dalam perkara ini adalah didasarkan pada putusan Sungguminasa dalam perkara Nomor 37/Pdt.G/1998/PN.Sungg yang telah berkekuatan hukum tetap mempertimbangkan bahwa karena gugatan Penggugat dalam perkara Nomor 37/Pdt.G/1998/PN.Sungg. telah ditolak seluruhnya, maka berarti kedua perjanjian jual beli atas kedua bidnag tanah objek sengketa tersebut adalah sah (vide putusan Pengadilan tinggi Makassar);

- Bahwa amar putusan Pengadilan Negeri Sungguminasa Nomor 37/Pdt.G/1998/PN.Sungg ternyata tidak satupun amar putusan tersebut yang menyatakan bahwa Tergugat sekarang sebagai Penggugat adalah pemilik kedua objek perkara;

- Bahwa karena tidak terbukti bahwa Penggugat adalah pemilik objek sengketa, maka tidak beralasan untuk menyatakan sah gugatan pengosongan tanah objek sengketa dan menghukum Tergugat untuk menyerahkan tanah tegalan kepada Penggugat;

- Bahwa berdasarkan pertimbangan di atas, Mahkamah Agung berpendapat terdapat cukup alasan untuk mengabulkan permohonan Peninjauan Kembali yang diajukan oleh Hajjah Hajiah, BA. Binti Rabana dan membatalkanputusan Pengadilan Tinggi Makassar Nomor 44/PDT/2010/PT.MKS. tanggal 13 April 2010 dan putusan Mahkamah Agung RI Nomor 2419K/Pdt/2010 tanggal 21 Maret 2011 serta Mahkamah Agung akan mengadili kembali Perkara ini yang seluruh amarnya berbunyi seperti yang akan disebutkan dibawah ini;

- Bahwa oleh karena permohonan peninjauan kembali dikabulkan, maka Termohon Peninjauan Kembali/Penggugat harus dihukum untuk membayar biaya perkara dalam pemeriksaan peninjauan kembali ini;

- Memperhatikan Undang - Undang Nomor 48 Tahun 2009 tentang Kekuasan Kehakiman, Undang - Undang Nomor 14 Tahun 1985 tentang Mahkamah Agung sebagaimana telah diubah dengan Undang - Undang Nomor 5 Tahun 2004 dan perubahan kedua dengan Undang - Undang Nomor 3 Tahun 2009 serta peraturan perundang undangan lain yang bersangkutan.

Pada putusan tersebut sudah memiliki kepastian hukum dimana putusan terdapat hal - hal yang harus terpenuhi dengan dijalankannya putusan PK No. 634PK/PDT/2012 dengan cara membatalkan sertipikat karena adanya cacat administrasi. Dengan dilakukannya putusan Peninjauan Kembali tersebut hal ini memberikan afektifitas pasa kepastian hukum yang ingin dicapai.

\section{KESIMPULAN DAN SARAN}

Pembatalan akta tanah adalah pernyataan batal suatu tindakan hukum atas perbuatan hukum atas tuntutan pihak-pihak oleh Undang-Undang Pasal 11 ayat (3) Peraturan Menteri Agraria/Kepala BPN No. 11 Tahun 2016 tentang Penyelesaikan Kasus Pertanahan dibenarkan untuk menuntut pembatalan tersebut. Akibat hukum pembatalan Hak Milik Atas Tanah berdasarkan Putusan Pengadilan maka akta berdasarkan jual beli tanah tersebut batal dan tanah sengketa menjadi hak milik dari penggungat, akibat dari pembatal akta Pejabat Pembuat Akta Tanah ini dilakukan oleh kesalahan sehingga mengakibatkan cacat administrasi pada akta tanah.

Bahwa berdasarkan pertimbangan Majelis Hakim sesuai Putusan Pengadilan Negeri Sungguminasa No. 40/PDT.G/2008/PN.SUNGG tanggal 30 September 2009 Jo. Substansi Pembatalan adalah membatalkan Sertipikat Hak Milik No. 01006/Panciro tanggal 28 November 2013 sebagaimana diuraikan dalam Surat Ukur No. 00541/Panciro 2013 tanggal 15 November 2013, seluas 5.596 M2, sampai saat ini tercatat atas nama DRS. H. A. SALAM MANRUPPAI yang terletak di Desa Panciro, Kecamatan Bajeng, Kabupaten Gowa, Provinsi Sulawesi Selatan dalam daftar umum dan daftar isian lainnya yang ada pada administrasi pendaftaran serta mematikan buku tanahnya sesuai ketentuan yang berlaku.

\section{DAFTAR PUSTAKA}

Boedi Harsono. 2005. Sejarah Pembentukan Undangundang Pokok Agraria. Isi dan Pelaksanaannya. Djambatan, Jakarta.

Muh. Imran Hamid Dm, S.H, Kepala Sub Seksi Penanganan Sengketa, Konflik dan Perkara Pertanahan, Wawancara dilaksanakan pada hari Senin, tanggal 02/11/2020. Pukul 11:32 di Kantor Pertanahan Kabupaten Gowa

UU No. 5 Tahun 1960 tentang Peraturan Dasar Pokokpokok Agraria.. LN No. 104 Tahun 1960. TLN No. 2013

Sirih, S. H., Ismail, I., \& Juharni, J. (2019). Strategi Pengembangan Sumber Daya Manusia Pada BKPSDM Kabupaten Majene. Jurnal Paradigma Administrasi Negara, 1(2), 5-11. 